\title{
Ambiguous Policy on Securing the Vital Objects of The Indonesian Armed Forces in East Java
}

\author{
Muhammad Risahdi ${ }^{1}$, Murtir Jaddawi ${ }^{2}$, Mansyur $^{3}$, Andi Henny ${ }^{4}$, Lukman Yudho Prakoso ${ }^{5}$ \\ Wuri Retno Martani ${ }^{*}$ \\ ${ }^{1}$ Student of Doctoral Programme of IPDN, Jatinangor, Indonesia \\ ${ }^{2,3,4}$ Lecturer of IPDN, Jatinangor, Indonesia \\ ${ }^{5}$ Lecturers of Sea Defense Strategy of Indonesia Defense University, IPSC, Sentul-Bogor, Indonesia \\ ${ }^{6}$ Student of Magister Programme of Indonesia Defense University, IPSC Sentul-Bogor, Indonesia. \\ *E-mail of the corresponding author: wuri.retno.martani@gmail.com
}

\begin{abstract}
.
The World Maritime Axis Policy President of the Republic of Indonesia, places the defense sector as one of the main pillars that must be prepared optimally to secure the territory of the Unitary State of the Republic of Indonesia. Safeguarding vital objects of the Indonesian National Army (TNI) is a priority to anticipate potential threats. The biggest strength of the Navy is at the East Java 2nd Fleet Command which is very strategic in securing Indonesia's territory, where most of its territory is sea. On this basis, researchers carry out research aimed at analyzing how the security of vital TNI objects, especially in their territorial waters at the 2nd Fleet Command Headquarters, East Java . supporting and inhibiting factors for implementation and formulating the best policy models for securing vital objects. The research method used was descriptive qualitative with a phenomenological approach. The theory used is the theory of implementation of public policy George Edward III. The results showed that the communication variables, dispositions and bureaucratic structures were relatively well run, while the resource variables found inhibiting factors related to the budget, human resources and facilities / infrastructure. As a theoretical criticism in this study, the existence of policy ambiguity in determining the Defense Area Plan (RWP) and the Detailed Defense Area Plan (RRWP) which became the operational basis for securing vital objects, especially the TNI until this research was implemented, did not yet exist. This is due to the strong interests of stake holders related to defense, economic and environmental interests. So in conclusion this research is that the implementation of the policy of securing vital objects of the TNI cannot be realized optimally if there is still policy ambiguity. So that the recommendation of this study is that an independent institution is needed which can be a driving force of policies in the field of national vita object security.
\end{abstract}

Keywords: Vital Object, Indonesian National Armed Forces, Ambiguity

DOI: $10.7176 /$ PPAR/10-1-08

Publication date: January $31^{\text {st }} 2020$

\section{Introduction}

Maritime policy is a necessity towards the development of maritime defense forces that have given birth to a new defense vision, one of which is the strengthening of the military fleet (Nugroho, 2014). The strength of the military fleet is very dependent on the readiness of the Indonesian warship as the main force as well as the Navy's operating unit under the Indonesian Fleet Command Region.

This readiness is inseparable from the function of the Indonesian Navy Main Base which has responsibility in supporting the operating unit to provide support for landing facilities, maintenance and repair facilities, debriefing facilities, facilities for personnel, facilities for building bases / sea security and empowerment of the sea (Orgaspros Pangkalan Utama TNI AL V, 2010). The five facilities referred to have adopted the function of naval bases in all countries, namely $4 \mathrm{R}$, rest, recreation, repair and replenishment which are continually being improved so as to be able to receive and provide support for elements of other navies as a world class Indonesian Navy (TNI Angkatan Laut Berkelas Dunia: Paradigma Baru, 2010). The creation of bases with world standards is one parameter of government support for the power of maritime defense to support the concept of a maritime state.

Another event caused by the weakness of the early detection system in sea security was the failure of the US Navy to detect sabotage in the form of suicide bomb attacks against USS Cole who were leaning and refueling at the Yemen port in October 2000 which was a phenomenon of how important the system safeguarding the Indonesian Fleet Command Base in the East Surabaya Region from the sea aspect (Tempo, 2010). This event is not only a form of weakness of the early detection system but shows a low sense of security about the possibility of an attack by the enemy against the warship. 
The success in establishing safeguards against bases in the aspect of the sea will provide a strategic phenomenon towards the security situation of Indonesian waters. The optimal security pattern will provide a deterrent effect on various threats while at the same time impacting the comfort of the warship crew during leaning, if these conditions are created then warships of other countries that are on duty around the Pacific Ocean will not hesitate to apply for support at the Navy Base. The interest of other warships to lean on the Indonesian Navy Base is a reflection of the security of the sea in an area that will invite foreign commercial ships to cross and even lean on Indonesian ports. So it is hoped that there will be no more unsecured reasons for the prospect of developing international standard ports.

\section{Method and Theory}

The researcher used the opportunity to determine, search, collect, process and analyze social interactions about factors that could influence the ability of the Indonesian Navy's main base in securing the Indonesian Fleet base from the sea aspect. Data collection is obtained from observations, documentation, interviews and joint / triangulation (Sugiyono, 2007). Primary sources in the research as interviewees have involved relevant informants in the implementation of security at the Indonesian's naval base, including Head of Tanjung Perak Port Authority Surabaya as an object and competent subject in the field of direct and indirect security. research locus at the Indonesian Navy's 2nd Fleet Base Surabaya.

The method used in this study is descriptive qualitative, phenomenology. The informants involved were all stake holders related to law enforcement in all entities involved in security base of the Indonesian navy 2 nd fleet. The theory used to answer the research problem formulation according to George Edward III, Edward proposed four factors that play an important role in achieving successful implementation or failure of policy implementation, namely communication, resources, disposition, and bureaucratic structure factor (Edwards III, 1980).

\section{Analysis and Discussion}

The conditions found as a form of existing conditions, the policy of the Main Base in securing the Indonesian Fleet base from the sea aspect are as follows;

\section{Tthe implementation of policies to protect national vital objects.}

3.1.1 Communication transmission. Security communication networks have not yet been established Command centers, Communication facilities are not in accordance with AL communication procedures.

3.1.2 Clarity of communication. There has not been a Patrol Unit involved in securing the base routinely, there are differences in interpretation between the Main Base and the KRI in the security of the base.

3.1.3 Communication consistency. The marine patrol unit is still receiving assignments from the staff above, still involved special force as a routine patrol unit.

3.1.4 Human resources. insufficient quality and quantity of personnel, resistance in increasing the competence of the security press, especially personnel entering the age before retirement.

3.1.5 Information in resources. The results of evaluations in the implementation of the training have not described the conditions / capabilities for securing the Main Sea Base.

3.1.6 Authority: the basis of the policy has been supported based on:

- Law of The Republic of Indonesia: 34 of 2004 concerning The Indonesian armed forces

- Regulations of Indonesian Navy Chief of Staff Number: 93/2009 concerning Security of Vital Object

- Regulations Indonesian Navy Chief of Staff Number:92 of 2009 concerning Headquarters Security

- Standart Operating Prosedure of Indonesian;s Naval Base

3.1.7 Facilities. Facilities in the form of security support for the Main Base are inadequate

3.1.8 Bureaucracy. The basis for implementing security procedures is different from manuals, the basis of which is used as a security procedure manual, only focusing on aspects of disturbance, not yet on the threat aspect, security procedures have not included the echelon/entity capabilities involved.

3.1.9 Disposition / attitude:. The attitude of leaders at Headquarters and Implementing Command supports the importance of security of bases from the aspect of the sea. 
3.2 Obstacle and Supporting Faktors.

This research obtained the findings of factors that influence the security of vital objects at the Surabaya 2nd Fleet Command Base as follows:

3.2.1 Obstacle factors. The dominant inhibiting factor in the analysis of the Main Base policy in securing the RI Fleet base from the sea aspect are:

- Implementation of transmission factors in the aspect of communication has not gone well, because the means of communication as a direct control function in ensuring the implementation of security policies from the sea aspect to the base have not been well realized, the 5th naval base of the navy as security implementers has not been able to establish a communication system in the field of security The inability is also supported by the absence of tactical communication centers listed in the Main Base security procedures.

- Leader echelon assistants have not been consistent with security procedures related to command control of the implementing elements below, giving rise to uncertainty in the involvement of the Main Base Patrol unit organization as the executing echelon, accompanied by differences in understanding and interpretation between echelon auxiliary leaders and special forces including naval vessels, about the use of supporting forces in carrying out security.

- The Main Base security policy from the aspect of the sea has not referred to the policies that apply above and there are differences in the implementation of these policies resulting in inconsistencies in the realization of the Indonesian Armada base security policy from the aspect of the sea. The effect of inconsistency in the involvement of implementing / supporting echelon is the emergence of selfinterpretation of information as a common obstacle, namely the non-optimal involvement of the Main Base and Passion Patrol Unit in securing the Indonesian Fleet base.

- The problem of human resources is dominated by a lack of quality and quantity personnel in echelons associated with the Main Base Station and vital objects around the Main base caused by the resistance of personnel approaching retirement age and the degradation of the number of personnel due to the implementation of personnel standards, which is not in favor of the extent of the assigned task area.

- The evaluation carried out has not been able to display various limitations in the aspects of facilities, personnel and methods possessed by the implementing echelon of the RI Fleet base security policy from the sea aspect by the Main Base. So that a variety of important information about these limitations has not been conveyed properly to the leadership who are able to make the echelon of leaders become resistant to the development of the ability to secure the sea against the Indonesian Fleet base.

- Supporting facilities for securing the Indonesian Armada base, especially from the sea aspect, are still inadequate, even far from the ideal conditions that are expected so that facilities support is needed so that the Main Base can be more optimal in carrying out security of the Indonesian Fleet base, especially from the sea aspect.

- Naval Base security procedures cannot yet be used as a Standard Operation Procedure (SOP) in securing the Indonesian Armada base and there needs to be an in-depth study of Main Base security procedures to avoid obstacles in the implementation of security for the Indonesian Armada base from the sea aspect while creating uniformity and understanding in each echelon.

3.2.2 Supporting factors. The dominant supporting factors from the results of research on the analysis of the Main Base policy in securing the Indonesian Fleet base from the sea aspect are:

- Disposition factor. Various attitudes of policy makers and echelon executing policies strongly support and understand the importance of safeguarding the Indonesian Armada Base from the aspect of the sea. The security conditions currently recognized have not been implemented properly so that it needs to be carried out revitalization both on the basis of policies, the composition of personnel and facilities in implementing security policies to secure the Indonesian Fleet base from the sea aspect.

- Authority factor. The variable of the Main Base authority in securing the Indonesian Fleet base has been very strong because it is supported by regulations up to the law level. The power of the authority variable has embodied the understanding that the authority and duties and responsibilities of the base functions, including security, are the domain of the Base Commander even though they are in the area of the Chairperson who has a higher position structure and is supported by greater resources. 


\subsection{Novelty}

Novelty model of security policy for vital objects. The results of the analysis of the discussion of the implementation of the security policy for vital objects Headquarters Command of Fleet II East Java, especially in the territorial waters led to a model of national vital object security policy in the form of the need to form an independent institution or body that is free from the interests of certain entities as a solution in making decisions due to the impact ambiguous policy. It is hoped that the existence of this independent institution / body can certainly ensure the implementation of the security policy on strategic vital objects, both organic and nonorganic, of the Indonesian armed forces, effectively and efficiently.

Ambiguity that occurs in securing the vital objects of the Indonesian armed forces, due to various factors that affect the overlapping of authority, due to the large number of entities involved and having their respective policy bases, this is consistent with the theory of ambiguity expressed by Richard Matland (Richard E, 1995).

\section{Conclusions.}

- Implementation of Safeguarding Vital Objects of the Indonesian armed forces, at the Armada Command Headquarters II. The implementation of securing national vital objects, especially the marine area of military agencies, East Java Fleet II Command Headquarters cannot be implemented because the national vital objects security policy based on Presidential Decree No.63 of 2004 should be followed up with several other policies such as the policy of the Minister of Defense of the Republic of Indonesia No . 138 of 2018, Concerning Defense Areas and Defense Area Plans, this policy came out with a vulnerable period of time to complete Presidential Decree No. 63 of 2004. Furthermore, Decree of the Minister of Defense of the Republic of Indonesia No.138 of 2018 can be operationalized if the Detailed Area of Defense Plan (RRWP) already exists, but until the researchers wrote this Desertation RRWP did not yet exist so that the legal aspects of securing the vital vital strategic objects of the Indonesian armed forces to the East Java Fleet II Base were not able to at this time, and caused ambiguity towards the implementation of security policies in the field.

- The security policy of the strategic vital objects of the Indonesian armed forces is very urgent to be addressed immediately so that it can be implemented because it greatly affects the stability of the state and nation in the present and the future. The current research makes East Java Armada Base II which is the Indonesian Armed Forces Naval Base which is ideal as a research ojek, while other vital strategic objects of the Indonesian armed forces have similar problems and require the same attention regarding aspects of security policy.

- The absence of a detailed Regional Defense Plan (RRWP) that has not yet become a major obstacle to the implementation of Presidential Decree No. 63 of 2018 concerning Safeguarding of National Vital Objects is very closely related to the Government's attitude regarding the National Defense Posture in addressing the Maritime Axis Policy.

- The model recommendation for the security of the East Java Base Fleet II from the marine aspect is the establishment of an independent institution that safeguards strategic vital objects to anticipate potential threats that can never be predicted when they come. The establishment of these institutions focused on making decisions about securing strategic vital objects, as well as carrying out supervision of the implementation and authorized to carry out periodic evaluations. Institutions that are independent in implementing the policy of securing strategic vital objects consist of people who have competence in their fields related to the security of national vital objects and come from multi-interested parties.

\section{References:}

Adityo Nugroho (2014), Visi Kemaritiman, Visi Pertahanan Baru Kementerian Pertahanan. Jurnal maritim Visi Kemaritiman, Visi Pertahanan Baru Kementerian Pertahanan.

Edwards III, George C. 1980. Implementing Public Policy. Washington, D.C: Congressional Quarterly Press. Law of The Republic of Indonesia Number: 34 of 2004 concerning The Indonesian armed forces

Matland, Richard E. (1995). "Syntesizing the Implementation". Journal of Public Administration Research and Theory

Orgaspros Pangkalan Utama TNI AL V (2010)

Regulations of Indonesian Navy Chief of Staff Number: 93/2009 concerning Security of Vital Object.

Regulations Indonesian Navy Chief of Staff Number:92 of 2009 concerning Headquarters Security.

Standart Operating Prosedure of Indonesian Naval Base. 
Sugiyono, Metode Penelitian Kuantitatif Kualitatif dan R \& D, Karya Dinamika Pustaka (2007), Yogyakarta, p 74.

Tempo (2010). Pengebom Kapal Perang AS Tetap Pakai Pengacaranya, http://www.tempo.co/read/news/2014/02/20/116555833/Pengebom-Kapal-Perang-AS-Tetap-PakaiPengacaranya, acces at June8th, 2019

TNI Angkatan Laut Berkelas Dunia: Paradigma Baru (2010), p 47 